\title{
PENGARUH KUALITAS PRODUK DAN PROMOSI TERHADAP KEPUTUSAN PEMBELIAN PADA SMARTPHONE MADE IN CHINA DI KECAMATAN CIKUPA KABUPATEN TANGERANG
}

\author{
Lita Novianti, Lod Sulivyo \\ Sekolah Tinggi Ilmu Ekonomi Ppi
}

\begin{abstract}
Abstrak
Penelitian ini bertujuan untuk menganalisis dan mengetahui apakah terdapat pengaruh Kualitas Produk dan Promosi terhadap Keputusan Pembelian Smartphone Made in China di Kecamatan Cikupa Kabupaten Tangerang. Sample yang digunakan dalam penelitaian ini sebanyak 100 responden dan pengambilan sampel menggunakan teknik purposive sampling. Pada penelitian kali ini, analisis yang dilakukan menggunakan bantuan Aplikasi Software SPSS Versi 23. Sedangkan teknik pengujian data yang dilakukan dalam penelitian ini adalah uji validitas, uji reliabilitas, uji normalitas, analisis korelasi parsial, koefisien determinasi, uji linier berganda, dan uji hipotesis (uji $\mathrm{t}$ dan uji f). bedasarkan hasil analisis korelasi parsial dapat diketahui nilai pengaruh korelasi variabel Kualitas Produk dan Promosi terhadap Keputusan Pembelian masing masing sebesar 0,533 dan 0,648. Sedangkan hasil analisis korelasi berganda memperlihatkan hasil nilai $\mathrm{R}^{2}$ ( $\mathrm{R}$ Square $)=50.8 \%$. Hal ini menunjukan bahwa Kualitas Produk (X1) dan Promosi (X2) secara simultan berpengaruh signifikan terhadap Keputusan Pembelian (Y) dengan nilai Koefisien Determinasi sebesar 49,8\% sedangkan sisanya $50,2 \%$ dipengaruhi oleh faktor lain yang tidak diteliti oleh peneliti.
\end{abstract}

Kata kunci : Kualitas produk, promosi, keputusan pembelian, smartphone

\section{PENDAHULUAN}

Perkembangan di era modern saat ini adalah teknologi informasi dan komunikasi. Teknologi informasi dan komunikasi kini menjadi kebutuan yang penting bagi kalangan masyarakat. Kebutuhan tersebut berdampak pada meningkatnya permintaan akan berbagai jenis alat komunikasi yang mengakibatkan semakin banyaknya persaingan dalam dunia bisnis dibidang teknologi komunikasi. Hal tersebut biasa dilihat dari banyaknya produsen yang membuat produk-produk alat komunikasi (Smartphone) yang menawarkan jenis produk baru dengan inovasi dari produk sebelumnya yang sudah beredar dikalangan masyarakat. Dimana produk yang dihasilkan banyak memberikan kemudahan bagi para konsumen dalam melakukan aktivitas pekerjaan dan komunikasi. Kemunculan berbagai perusahaan dalam dunia komunikasi khususnya perusahaan Smartphone menuntut adanya keunggulan bersaing yang harus dimiliki oleh setiap perusahaan agar mampu bersaing. Kemajuan perekonomian dan teknologi yang terus berkembang menyebabkan semakin meningkatnya kapasitas pemakaian dan kebutuhan dalam dunia komunikasi. Kegunaan handphone saat ini bukan hanya sekedar telefon dan SMS (Short Massage Service) saja, tetapi berkembang menjadi sebuah produk yang memiliki banyak kegunaan. Berkembangnya handphone menjadi smartphone menimbulkan banyak persiangan bisnis di dalam industry teknologi informasi dan komunikasi. 
Smatphone saat ini menjadi kebutuhan penting bagi setiap orang dan memberikan dampak yang sangat besar bagi kehidupan manusia. Maka tidak aneh apabila para produsen saling bersaing untuk mendapatkan keuntungan dari pangsa pasar di Indonesia. Terlebih lagi masyarakat Indonesia masih gemar menggunakan barang - barang buatan China khususnya barang-barang elektronik karena kualitasnya yang mulai membaik dan perbandingan harga yang menjadi salah satu alasan untuk membeli produk made in China.

\section{Gambar 1.1}

\section{Penjualan Smartphone Di Indonesia sejak 2019-September 2020}

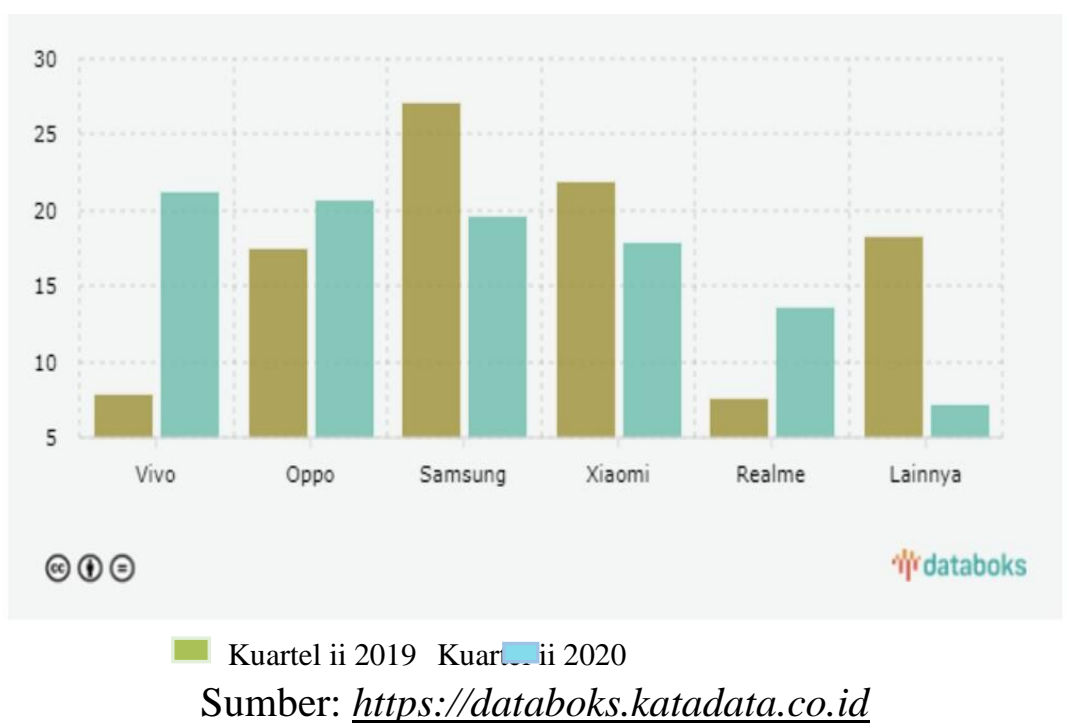

Dari data diatas Vivo menjadi merek dengan penjualan terbesar. Merek asal China itu mampu meraup pasar penjualan hingga $21,2 \%$ pada kuartal II-2020. Di posisi berikutnya ada Oppo (20,6\%) dan Samsung (19,6\%).(Baca: Huawei Dominasi Pasar Smartphone Global di Kuartal Kedua 2020) Kunci keberhasilan Vivo terlihat dalam strategi harga, ditambah lagi permintaan yang besar pada segmen kelas menengah bawah. Ponsel pintar Vivo dengan tipe Y12, Y91C, dan Y50 adalah sejumlah penyumbang terbesar pada nilai pasarnya. Kekuatan Vivo berasal dari segmen luar jaringan (luring). Smartphone made in China dapat menjadi pesaing yang berat bagi smartphone yang lain. Dengan kondisi penjualan tersebut maka dengan sendirinya akan menciptakan adanya perbedaan persepsi konsumen atas produk yang ditawarkan oleh perusahaan smatphone China. Salah satu faktor yang dapat mempengaruhi keputusan pembelian konsumen adalah kualitas produk.

Kualitas produk merupakan salah satu komponen penting dalam menciptakan maupun mempertimbangkan strategi dalam suatu perusahaan, apabila kualitas produk yang dihasilkan bagus maka akan menjadi daya tarik tersendiri bagi konsumen dalam menentukan pilihan untuk membeli suatu produk, sebaliknya jika kualitas produk buruk atau tidak sesuai dengan harapan, maka konsumen akan beralih pembeliannya pada produk yang sejenis lainnya. Untuk mencapai kualitas produk yang diharapkan maka diperlukan suatu standarisasi kualitas, cara ini bertujuan untuk menjaga produk yang dihasilkan mampu memenuhi standar yang telah ditetapkan sehingga tepat pada 
segmentasi pasar yang dituju. Suatu produk dapat dikatakan berkualitas jika produk tersebut memenuhi kebutuhan dan keinginan pembeli.

Promosi merupakan hal yang sangat penting bagi perusahaan dalam mengkomunikasikan produk kepada konsumen, selain menawarkan produk yang berkualitas. Promosi merupakan kegiatan yang dilakukan perusahaan untuk menunjukan keistimewaan - keistimewaan produk dan membujuk konsumen untuk membeli. Strategi promosi merupakan gabungan antara periklanan, penjualan perorangan, promosi penjualan, dan publisitas menjadi suatu program terpadu untuk berkomunikasi dengan pembeli dan orang lain yang pada akhirnya akan mempengaruhi keputusan pembelian.

Keputusan pembelian merupakan salah satu faktor yang harus dipertimbangkan, karena seluruh stategi yang telah disiapkan akan berakhir pada keputusan pembelin para konsumen. Selain itu, keputusan pembelian termasuk suatu hal yang sangat penting untuk diperhatikan karena keputusan pembelian dijadikan acuan oleh perusahaan untuk menciptakan stategi pemasaran produk yang akan dijual salah satunya dengan mengetahui kebutuhan konsumen, selera dan keinginan dari para konsumen. Pemahaman yang mendalam terhadap konsumen akan memungkinkan pasar untuk mampu mempengaruhi proses keputusan pembelian konsumen, sehingga mau membeli produk yang ditawarkan.

Dalam persaingan Smartphone pada pangsa pasar Indonesia, produk smartphone made in China mulai bersaing dengan produk smartphone yang lain. Merek smartphone ini melakukan stimulus pemasaran ke konsumen agar konsumen tertarik dan membeli produk smartphone made in China. Faktor stimulus pemasaran yang dilakukan dari segi harga, kualitas produk, desain produk dan promosi. Bila dilihat dari segi harga, harga yang ditawarkan smartphone made in china ini lebih murah dibandingkan dengan merek smartphone non china. Dari segi promosi, smatphone made in China melakukan promosi penjualan yang bersaing, tetapi promosi yang di lakukan biasanya berupa pemberian voucher, pemberian rewaed, dan diskon. Dari segi kualitas dan desain produk, pada era globalisasi jaman sekarang ini dimana teknologi sudah sangat maju, maka kualitas produk dan desain produk bisa ditetapkan dengan menerapkan standarisasi pada smartphone, sehinga smatphone made in China memiliki keunggulan masing-masing.

\section{LANDASAN TEORI}

\section{Kualitas Poduk}

Pada dasarnya dalam membeli suatu produk, seorang konsumen tidak hanya membeli produk, akan tetapi konsumen jga membeli manfaat atau keunggulan yang dapat diperoleh dari produk yang dibelinya. Oleh karena itu, suatu produk harus memiliki keunggulan dari produk-produk yang lain, salah satunya dari segi kualitas produk yang ditawarkan. Kualitas poduk merupakan salah satu kunci persaingan diantara pelaku usaha yang ditawarkan kepada konsumen. Berikut ini merupakan pengertian kualitas produk menurut para ahli.

Menurut Kotler dan Amstrong (2014:11), kualitas produk adalah kemampuan sebuah produk dalam memperagakan fungsinya, hal ini termasuk keseluruhan durabilitas, reliabilitas, ketepatan, kemudahan pengoprasian, dan reparasi produk, juga atribut produk lainnya. Menurut Kotler \& Keller (2016:164), kualitas produk adalah kemampuan suatu barang untuk memberikan hasil atau kinerja yang sesuai bahkan 
melebihi dari apa yang diinginkan pelanggan. Menurut Mowen (2012:61), kualitas produk merupakan proses evaluasi secara keseluruhan kepada pelanggan atas perbaikan kinerja suatu produk. Indikator kualitas produk menurut Menurut David Garvin dalam buku Fandy Tjiptono (2016:134) mengemukakan, bahwa kualitas produk memiliki beberapa indikator antara lain:

a. Kinerja (Performance), merupakan karakteristik operasi dan produk inti (core product) yang dibeli. Misalnya kecepatan, kemudahan dan kenyamanan dalam penggunaan.

b. Ciri-ciri atau keistimewaan tambahan (Features), yaitu karakteristik sekunder atau pelengkap.

c. Kesesuaian dengan spesifikasi (Conformance to Spesification), yaitu sejauh mana karakteristik desain dan operasi memenuhi standar yang telah ditetapkan sebelumnya. Misalnya pengawasan kualitas dan desain, standar karakteristik operasional.

d. Keandalan (Realibility), yaitu kemungkinan kecil akan mengalami kerusakan atau gagal pakai. Misalnya pengawasan kualitas dan desain, standar karakteristik operasional.

e. Daya tahan (Durability), berkaitan dengan berapa lama produk tersebut dapat terus digunakan. Dimensi ini mencakup umur teknis maupun umur ekonomis.

f. Estetika (Esthetica), yaitu daya tarik produk terhadap panca indera. Misal keindahan desain produk, keunikan model produk, dan kombinasi.

g. Kualitas yang dipersepsikan (Perceived Quality), merupakan persepsi konsumen terhadap keseluruhan kualitas atau keunggulan suatu produk. Biasanya karena kurangnya pengetahuan pembeli akan atribut atau ciri-ciri produk yang akan dibeli, maka pembeli mempersepsikan kualitasnya dari aspek harga, nama merek, iklan, reputasi perusahaan, maupun negara pembuatnya.

h. Dimensi kemudahan perbaikan (Serviceability), meliputi kecepatan, kemudahan, penanganan keluhan yang memuaskan. Pelayanan yang diberikan tidak terbatas hanya sebelum penjualan, tetapi juga selama proses penjualan hingga purna jual yang mencakup pelayanan reparasi dan ketersediaan komponen yang dibutuhkan.

\section{Promosi}

Menurut Rambat Lupiyoadi (2013:92) mendefinisikan pengertian promosi adalah kegiatan yang dilakukan perusahaan untuk mengkomunikasikan manfaat produk dan sebagai alat untuk mempengaruhi konsumen dalam kegiatan pembelian atau penggunaan jasa sesuai dengan kebutuhan. Menurut Tjiptono (2015:387) promosi merupakan elemen bauran pemasaran yang berfokus pada upaya menginformasikan, membujuk, dan mengingatkan kembali konsumen akan merek dan produk perusahaan.

Sedangkan menurut Kotler (2012:10) promosi adalah usaha yang dilakukan oleh marketer, berkomunikasi dengan calon audiens bahwa dengan komunikasi merupakan proses membagi ide, informasi, atau perasaan audiens. Menurut M. Mursid (2017:9699), mengatakan ada empat jenis indikator promosi sebagai berikut :

a. Periklanan (Advertising)

Periklanan dipandang sebagai kegiatan penawaran kepada suatu kelompok masyarakat baik secara langsung lisan maupun dengan penglihatan (berupa berita) tentang suatu produk, jasa, atau ide. Tetapi periklanan dilakukan dengan mengeluarkan sejumlah biaya, berbeda dengan publisitas yang disiarkan tanpa mengeluarkan biaya. Kegiatan periklanan berarti kegiatan menyebarluaskan berita 
(informasi) kepada pasar (masyarakat / konsumen). Masyarakat perlu diberitahu siapa (sponsor) yang bertindak melalui media iklan tersebut. Dalam hal ini pihak sponsor membayar kepada media yang membawakan berita tersebut. Dalam hal ini pihak sponsor membayar kepada media iklan tersebut. Kegiatan periklanan adalah suatu alat untuk membuka komunikasi dua arah antara penjual dan pembeli, sehingga keinginan mereka dapat terpenuhi dengan cara yang efektif dan efisien, dalam hal ini komunikasi dapat menunjukan cara-cara untuk mengadakan pertukaran yang saling memuaskan.

b. Personal Selling

Personal selling atau penjualan pribadi disini merupakan komunikasi persuasif seseorang secara individual kepada seseorang atau lebih calon pembeli dengan maksud menimbulkan permintaan (penjualan). Lain halnya dengan periklanan dan kegiatan promosi lainnya yang komunikasinya bersifat non pribadi atau missal dalam operasinya, personal selling lebih flaksibel dibandingkan dengan yang lain. Ini disebabkan karena tenaga-tenaga penjual tersebut dapat secara langsung mengetahui keingginan, motif, dan perilaku konsumen, dan sekaligus dapat melihat reaksi konsumen sehingga mereka langsung dapat mengadakan penyesuaian seperlunya.

c. Publisitas

Sejumlah informasi tentang sesorang, barang, atau organisasi/perusahaan yang disebarluaskan ke masyarakat dengan cara membuat berita yang mempunyai arti komersial atau berupa penyajian - penyajian yang lain yang bersifat positif. Dengan demikian suatu perusahaan beserta produknya dapat menjadi perhatian umum. Dapat saja terjadi bahwa seseorang atau organisasi tidak mengetahui kalau dirinya telah dipublikasikan. Untuk melakukan publisitas tidak perlu membayar, disinilah letak perbedaan antara publisitas dengan periklanan, dalam hal mana periklanan memerlukan sejumlah pembayaran. Suatu kenyataan bahwa berita berita periklanan dapat dibuat sebagai publisitas, dengan demikian juga publisitas dapat disiarkan sebagai iklan.

d. Sales Promotion

Alat kegiatan promosi selain periklanan, personal selling dan publisitas ialah sales promotion yang dilakukan dengan peragaan, pertunjukan dan pameran, demonstrasi dan berbagai macam usaha penjualan yang tidak bersifat rutin.

\section{Keputusan Pembelian}

Menurut Fandy Tjiptono (2014:21) keputusan pembelian adalah sebuah proses dimana konsumen mengenal masalahnya, mencari informasi mengenai produk atau merek tertentu dan mengevaluasi seberapa baik masing-masing alternatif tersebut dapat memecahkan masalahnya, yang kemudian mengarah kepada keputusan pembelian. Menurut Kotler dan Keller (2012:227) keputusan pembelian merupakan proses dimana konsumen melewati lima tahap, yaitu pengenalan masalah, pencarian informasi, evaluasi alternatif, keputusan pembelian, dan perilaku pasca pembelian, yang dimulai jauh sebelum pembelian aktual dilakukan dan memiliki dampak yang lama setelah itu. Menurut Philip Kotler yang diterjemahkan oleh A.B Susanto (2012:202) mengemukakan bahwa keputusan pembelian dapat diartikan sebagai suatu keputusan yang diambil oleh seorang calon pembeli menyangkut kepastian akan membeli atau tidak. 
Pada saat konsumen mengambil keputusan pembelian sesungguhnya merupakan kumpulan dari sejumlah keputusan yang teroganisir. Dan dalam keputusan pembelian terdapat enam dimensi keputusan pembelian menurut Kotler dan Keller (2012:178) yang terdiri dari :

a. Pilihan produk, dalam hal ini perusahaan harus memusatkan perhatiannya kepada orang-orang yang berniat membeli sebuah produk serta alternatifnya yang mereka pertimbangkan.

b. Pilihan merek, konsumen harus menjatuhkan pilihan pada merek apa yang akan dibeli.

c. Pilihan penyalur, konsumen harus menentukan penyalur mana yang dipilih untuk membeli produk. Dalam hal ini konsumen memilih penyalur dapat dikarenakan faktor lokasi yang dekat, harga yang murah, tersedianya barang yang lengkap dan kenyamanan pada saat membeli.

d. Jumlah pembeliaan, konsumen dapat menentukan kuantitas barang yang akan dibeli. Dalam hal ini perusahaan harus mempersiapkan banyaknya produk yang sesuai dengan keinginan konsumen yang berbeda-beda.

e. Waktu pembelian

\section{Kerangka Pemikiran}

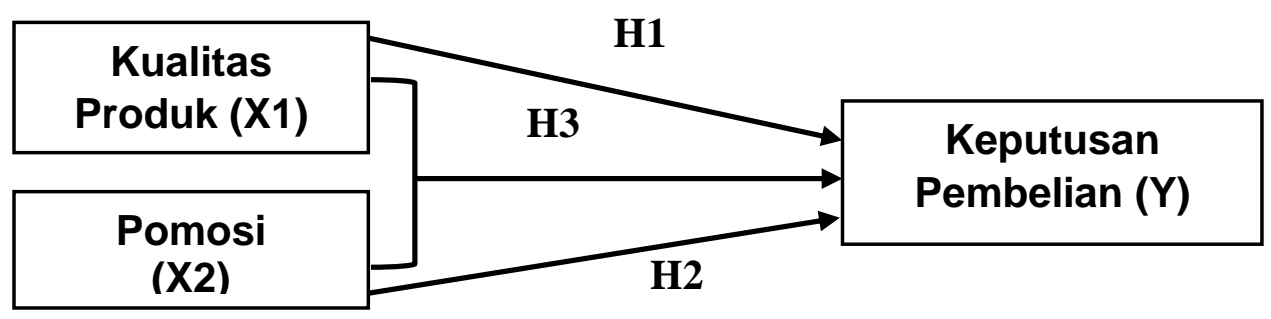

Keterangan:

H1: Pengaruh kualitas produk (X1) secara parsial terhadap keputusan pembelian (Y) pada Smartphone Made in China.

H2: Pengaruh promosi (X2) secara parsial terhadap keputusan pembelian (Y) pada Smartphone Made in China.

H3 : Pengaruh kualitas produk (X1) dan promosi (X2) secara simultan terhadap keputusan pembelian (Y) pada Smartphone Made in China.

\section{Hipotesis}

Hipotesis 1

Ha : Diduga terdapat pengaruh antara Kualitas Produk (X1) terhadap Keputusan Pembelian (Y) pada smartphone made in China.

Ho : Diduga tidak terdapat pengaruh antara Kualitas Produk (X1) terhadap Keputusan Pembelian (Y) pada smartphone made in China.

Hipotesis 2

Ha : Diduga terdapat pengaruh antara Promosi (X2) terhadap Keputusan Pembelian (Y) pada smartphone made in China. 
Ho : Diduga tidak terdapat pengaruh antara Promosi (X2) terhadap Keputusan Pembelian (Y) pada smartphone made in China.

Hipotesis 3

Ha : Diduga terdapat pengaruh antara Kualitas Produk (X1) dan Promosi (X2) terhadap Keputusan Pembelian (Y) pada smartphone made in China.

Ho : Diduga tidak terdapat pengaruh antara Kualitas Produk (X1) dan Promosi (X2) terhadap Keputusan Pembelian (Y) pada smartphone made in China.

\section{METODOLOGI PENELITIAN}

Metode penelitian yang digunakan dalam penelitian ini adalah menggunakan metode kuantitatif. Dalam penelitian ini, menggunakan metode kuantitatif yang digunakan untuk menganalisis tentang bagaimana pengaruh kualitas produk dan promosi terhadap keputusan pembelian pada smartphone made in China di kecamatan cikupa kabupaten tangerang. Dalam hal penelitian ini menggunakan data kualitatif yang akan diubah menjadi data kuantitatif. Data tersebut diperoleh melalui kuesioner/angket yang diolah dalam SPSS. Pengumpulan data dalam penelitian ini dengan teknik menyebarkan angket (kuesioner).

Populasi dalam penelitian ini ditujukan untuk konsumen yang membeli Smartphone made in China di Kecamatan Cikupa Kabupaten Tangerang. Sementara itu jumlah sampel yang digunakan dalam penelitian ini sebanyak 100 orang responden yang secara teori sudah cukup menghasilkan data yang akurat menurut Suharsimi Arikunto. Menurut Suharsimi Arikunto (2013:176), "teknik purposive sampling adalah teknik penentuan sample berdasarkan pertimbangan yang berfokus pada tujuan tertentu.

\section{HASIL PENELITIAN DAN PEMBAHASAN}

\section{Hasil Uji Validitas dan Reliabilitas}

a. Uji Validitas dan Reliabilitas Kualitas Produk (X1)

\begin{tabular}{|l|r|r|r|r|}
\hline \multicolumn{7}{|c|}{ Item-Total Statistics } \\
& $\begin{array}{c}\text { Scale Mean if } \\
\text { Item Deleted }\end{array}$ & $\begin{array}{c}\text { Scale Variance } \\
\text { if Item Deleted }\end{array}$ & $\begin{array}{c}\text { Corrected } \\
\text { Item-Total } \\
\text { Correlation }\end{array}$ & $\begin{array}{c}\text { Cronbach's } \\
\text { Alpha if Item } \\
\text { Deleted }\end{array}$ \\
\hline Kualitas Produk_1 & 27.82 & 18.816 & .287 & .726 \\
Kualitas Produk_2 & 27.83 & 18.769 & .335 & .716 \\
Kualitas Produk_3 & 27.73 & 19.452 & .252 & .730 \\
Kualitas Produk_4 & 28.04 & 16.160 & .578 & .664 \\
Kualitas Produk_5 & 27.81 & 17.994 & .464 & .692 \\
Kualitas Produk_6 & 27.91 & 18.285 & .353 & .713 \\
Kualitas Produk_7 & 28.03 & 16.797 & .504 & .681 \\
Kualitas Produk_8 & 28.06 & 16.158 & .580 & .664 \\
\hline
\end{tabular}

Berdasarkan tabel di atas, dapat diketahui bahwa setiap pernyataan pada variabel Kualitas Produk (X1),dari pernyataan kualitas produk 1 sampai 8 memiliki nilai yang valid, karena masing - masing pernyataan memiliki hasil perhitungan di atas 0,2. 
Sebagaimana tertera pada kolom Corrected Item-Total Correlation, sehingga dapat dilakukan uji analisis berikutnya.

Reliability Statistics

\begin{tabular}{|r|r|}
\hline Cronbach's Alpha & N of Items \\
\hline .727 & 8 \\
\hline
\end{tabular}

Berdasarkan table diatas, dapat diketahui bahwa variabel kualitas produk (X1) adalah reliabel, karena memiliki nilai Cronbach's Alpha > 0,60, yaitu 0,727.

b. Uji Validitas dan Reliabilitas Promosi (X2)

Item-Total Statistics

\begin{tabular}{|l|r|r|r|r|}
\hline & $\begin{array}{c}\text { Scale Mean if } \\
\text { Item Deleted }\end{array}$ & $\begin{array}{c}\text { Corrected } \\
\text { Scale Variance } \\
\text { if Item Deleted }\end{array}$ & $\begin{array}{c}\text { Cronbach's } \\
\text { Item-Total } \\
\text { Correlation }\end{array}$ & $\begin{array}{c}\text { Alpha if Item } \\
\text { Deleted }\end{array}$ \\
\hline Promosi_1 & 28.39 & 17.230 & .407 & .704 \\
Promosi_2 & 28.50 & 17.081 & .343 & .717 \\
Promosi_3 & 28.56 & 17.077 & .297 & .729 \\
Promosi_4 & 28.29 & 18.612 & .217 & .736 \\
Promosi_5 & 28.44 & 15.400 & .561 & .670 \\
Promosi_6 & 28.43 & 16.429 & .490 & .688 \\
Promosi_7 & 28.49 & 15.566 & .525 & .678 \\
Promosi_8 & 28.47 & 15.706 & .536 & .676 \\
\hline
\end{tabular}

Berdasarkan table di atas, dapat diketahui bahwa setiap pernyataan pada variabel Promosi (X2), dari pernyataan promosi 1 sampai 8 memiliki nilai yang valid, karena masing-masing pernyataan memiliki hasil perhitungan di atas 0,2 . Sebagaimana tertera pada kolom Corrected Item-Total Correlation, sehingga dapat dilakukan uji analisis berikutnya.

Reliability Statistics

\begin{tabular}{|r|r|}
\hline Cronbach's Alpha & N of Items \\
\hline .728 & 8 \\
\hline
\end{tabular}

Berdasarkan tabel diatas, dapat diketahui bahwa variabel kualitas produk telah reliabel, karena memiliki nilai Cronbach's Alpha > 0,60, yaitu 0,728.

c. Uji Validitas dan Reliabilitas Keputusan Pembelian (Y)

\begin{tabular}{|l|r|r|r|r|}
\hline & Item-Total Statistics & \\
& $\begin{array}{c}\text { Scale Mean if } \\
\text { Item Deleted }\end{array}$ & $\begin{array}{c}\text { Scale Variance } \\
\text { if Item Deleted }\end{array}$ & $\begin{array}{c}\text { Corrected } \\
\text { Item-Total } \\
\text { Correlation }\end{array}$ & $\begin{array}{c}\text { Cronbach's } \\
\text { Alpha if Item } \\
\text { Deleted }\end{array}$ \\
\hline Keputusan Pembelian_1 & 28.47 & 26.090 & .413 & .862 \\
Keputusan Pembelian_2 & 28.47 & 24.272 & .618 & .837 \\
Keputusan Pembelian_3 & 28.46 & 22.655 & .840 & .810 \\
Keputusan Pembelian_4 & 28.45 & 22.876 & .808 & .814 \\
Keputusan Pembelian_5 & 28.42 & 22.509 & .839 & .810 \\
Keputusan Pembelian_6 & 28.41 & 23.557 & .814 & .816 \\
Keputusan Pembelian_7 & 28.33 & 28.163 & .266 & .874 \\
Keputusan Pembelian_8 & 28.42 & 27.680 & .283 & .875 \\
\hline
\end{tabular}


Berdasarkan table di atas, dapat diketahui bahwa setiap pernyataan pada variabel Keputusan Pembelian (Y), dari pernyataan Keputusan Pembelian 1 sampai 8 memiliki nilai yang valid, karena masing-masing pernyataan memiliki hasil perhitungan di atas 0,2. Sebagaimana tertera pada kolom Corrected Item-Total Correlation, sehingga dapat dilakukan uji analisis berikutnya.

\begin{tabular}{|c|c|}
\hline \multicolumn{2}{|c|}{ Reliability Statistics } \\
\hline Cronbach's Alpha & $\mathrm{N}$ of Items \\
\hline .857 & 8 \\
\hline
\end{tabular}

Berdasarkan tabel diatas, dapat diketahui bahwa variabel kualitas produk telah reliabel, karena memiliki nilai Cronbach's Alpha > 0,60, yaitu 0,857.

\section{Hasil Uji Korelasi Parsial}

a. Uji Korelasi kualitas produk (X1) terhadap keputusan pembelian (Y)

\begin{tabular}{|ll|r|r|}
\hline \multicolumn{2}{|c|}{ Correlations } & \multicolumn{1}{c|}{$\begin{array}{c}\text { Keputusan_ } \\
\text { Pembelian }\end{array}$} & Kualitas_Produk \\
\hline Pearson Correlation & Keputusan_Pembelian & 1.000 & .533 \\
& Kualitas_Produk & .533 & 1.000 \\
\hline Sig. (1-tailed) & Keputusan_Pembelian &. & .000 \\
& Kualitas_Produk & 100 &. \\
\hline $\mathrm{N}$ & Keputusan_Pembelian & 100 & 100 \\
& Kualitas_Produk & 100 \\
\hline
\end{tabular}

Pada tabel Correlations diatas menampilkan nilai hubungan dan signifikansi antara variabel Kualitas Produk (X1) dengan Keputusan Pembelian (Y) sebesar 0,533 yang berarti terdapat hubungan yang positif yang cukup kuat antara variabel Kualitas Produk (X1) dengan Keputusan Pembelian (Y).

b. Uji Korelasi promosi (X2) terhadap keputusan pembelian (Y)

\begin{tabular}{|ll|r|r|}
\hline \multicolumn{2}{|c|}{ Correlations } \\
\hline Pearson Correlation & Keputusan_Pembelian & Promosi \\
& Keputusan_Pembelian & 1.000 & .648 \\
& Promosi & .648 & 1.000 \\
\hline Sig. (1-tailed) & Keputusan_Pembelian & .000 & .000 \\
& Promosi & 100 & 100 \\
\hline $\mathrm{N}$ & Keputusan_Pembelian & 100 & 100 \\
& Promosi & &. \\
\end{tabular}

Pada tabel Correlations diatas menampilkan nilai hubungan dan signifikansi antara variabel Promosi (X2) dengan Keputusan pembelian (Y) sebesar 0,648 yang berarti terdapat hubungan yang positif yang kuat antara variabel Promosi (X2) dengan Keputusan Pembelian (Y). 


\section{Uji Detemninasi $\left(\mathbf{R}^{2}\right)$ kualitas produk (X1) dan promosi (X2) terhadap keputusan pembelian (Y)}

\begin{tabular}{|l|r|r|r|r|}
\hline Model & $\mathrm{R}$ & R Square & $\begin{array}{c}\text { Adjusted R } \\
\text { Square }\end{array}$ & $\begin{array}{c}\text { Std. Error of the } \\
\text { Estimate }\end{array}$ \\
\hline 1 & $.713^{\mathrm{a}}$ & .508 & .498 & 3.987 \\
\hline
\end{tabular}

a. Predictors: (Constant), Promosi, Kualitas_Produk

Pada tabel diatas ditampilkan pengaruh Kualitas Produk (X1) dan Promosi (X2) terhadap Keputusan Pembelian (Y) Berdasarkan R Square secara simultan sebesar 0,508 atau 50,8\% dan sisanya 49,2\% dipengaruhi oleh faktor lain. Dan pada tabel ini juga ditampilkan pengaruh Kualitas Produk (X1) dan Promosi (X2) terhadap Keputusan Pembelian (Y) Berdasarkan Adjusted R Square secara simultan sebesar 0,498 atau 49,8\% dan sisanya 50,2\% dipengaruhi oleh faktor lain. Dan pada pada penelitian ini penulis lebih memilih menggunakan Adjusted R Square karena pengaruh yang lebih kecil secara statistic perhitungannya dianggap lebih akurat.

\section{Uji Regresi Berganda}

\begin{tabular}{|c|c|c|c|c|c|c|}
\hline \multicolumn{7}{|c|}{ Coefficients $^{\mathrm{a}}$} \\
\hline \multirow{2}{*}{\multicolumn{2}{|c|}{ Model }} & \multicolumn{2}{|c|}{ Unstandardized Coefficients } & \multirow{2}{*}{$\begin{array}{c}\text { Standardized } \\
\text { Coefficients }\end{array}$} & \multirow[b]{2}{*}{$\mathrm{t}$} & \multirow[b]{2}{*}{ Sig. } \\
\hline & & $\mathrm{B}$ & Std. Error & & & \\
\hline \multirow[t]{3}{*}{1} & (Constant) & -.488 & 3.338 & & -.146 & .884 \\
\hline & Kualitas_Produk & .386 & .093 & .325 & 4.173 & .000 \\
\hline & Promosi & .635 & .096 & .517 & 6.637 & .000 \\
\hline
\end{tabular}

a. Dependent Variable: Keputusan_Pembelian

Dari data hasil analisis, diperoleh konstan a dan b pada tabel coefficients yang dapat menujukan/ menghasilkan persamaan regresi serta dapat diinterpretasikan sebagai berikut:

a. Harga -0,488 merupakan nilai konstan (a) yang menunjukan bahwa jika tidak ada kenaikan kualitas produk, maka keputusan pembelian akan mencapai -0,488, sedangkan harga $0.386 \mathrm{X} 1$, merupakan koefisien regresi yang menunjukan bahwa setiap ada penambahan 1 angka untuk kualitas produk, maka akan ada kenaikan keputusan pembelian sebesar 0.386 .

b. Harga -0,488 merupakan nilai konstan (b) yang menunjukan bahwa jika tidak ada kenaikan promosi, maka keputusan pembelian akan mencapai $-0,488$, sedangkan harga $0.635 \mathrm{X} 2$, merupakan koefisien regresi yang menunjukan bahwa setiap ada penambahan 1 angka untuk promosi, maka akan ada kenaikan promosi sebesar 0.635 . 


\section{Uji Hipotesis}

\begin{tabular}{|c|c|c|c|c|c|}
\hline \multicolumn{6}{|c|}{ Coefficients $^{\mathrm{a}}$} \\
\hline \multirow[b]{2}{*}{ Model } & \multicolumn{2}{|c|}{ Unstandardized Coefficients } & \multirow{2}{*}{$\begin{array}{c}\text { Standardized } \\
\text { Coefficients }\end{array}$} & \multirow[b]{2}{*}{$\mathrm{T}$} & \multirow[b]{2}{*}{ Sig. } \\
\hline & $\mathrm{B}$ & Std. Error & & & \\
\hline $1 \quad$ (Constant) & 12.263 & 3.275 & & 3.744 & .000 \\
\hline Kualitas_Produk & .634 & .102 & .533 & 6.243 & .000 \\
\hline
\end{tabular}

a. Dependent Variable: Keputusan_Pembelian

Pada tabel koefisien diatas menunjukan nilai signifikansi t sebesar $0,000<0,05$ yang berarti Ho ditolak maka Ha diterima. Yang berarti terdapat pengaruh antara Kualitas Produk (X1) terhadap Keputusan Pembelian (Y) pada smartphone made in China.

\begin{tabular}{|c|c|c|c|c|c|}
\hline \multicolumn{6}{|c|}{ Coefficients $^{\mathrm{a}}$} \\
\hline \multirow[b]{2}{*}{ Model } & \multicolumn{2}{|c|}{ Unstandardized Coefficients } & $\begin{array}{l}\text { Standardized } \\
\text { Coefficients }\end{array}$ & & \\
\hline & $\mathrm{B}$ & Std. Error & Beta & $\mathrm{t}$ & Sig. \\
\hline (Constant) & 6.588 & 3.107 & & 2.120 & .036 \\
\hline Promosi & .797 & .095 & .648 & 8.417 & .000 \\
\hline
\end{tabular}

a. Dependent Variable: Keputusan_Pembelian

Dan pada tabel koefisien diatas menunjukan nilai signifikansi t sebesar $0,00>0,05$ yang berarti Ho ditolak maka Ha diterima. Berarti terdapat pengaruh antara Promosi (X2) terhadap Keputusan Pembelian (Y) pada smartphone made in China.

\begin{tabular}{|l|r|r|r|r|r|}
\hline Model & Sum of Squares & df & Mean Square & F & Sig. \\
\hline 1 Regression & 1591.407 & 2 & 795.703 & 50.068 & $.000^{\mathbf{b}}$ \\
Residual & 1541.583 & 97 & 15.893 & & \\
Total & 3132.990 & 99 & & & \\
\hline
\end{tabular}
a. Dependent Variable: Keputusan_Pembelian
b. Predictors: (Constant), Promosi, Kualitas_Produk

Pada Anova diatas ditampilkan nilai F sebesar 50.068 dan signifikansi sebesar $0.000<0,05$ yang maka Ho ditolak dan Ha diterima. Berdasarkan analisa diatas dapat diambil kesimpulan terdapat pengaruh Kualitas Produk dan Promosi terhadap Keputusan Pembelian Smartphone Made In China (secara simultan).

\section{KESIMPULAN}

Berdasarkan hasil analisis tentang kualitas produk dan promosi terhadap keputusan pembelian pada smartphone made in China di Kecamatan Cikupa Kabupaten Tangerang, penulis menarik kesimpulan sebagai berikut :

1. Dari hasil analisis data penelitian, didapat nilai hubungan (koefisien korelasi) antara variabel kualitas produk (X1) dengan keputusan pembelian (Y) pada smartphone China di Kecamatan Cikupa Kabupaten Tangerang sebesar 0,533 yang berarti terdapat hubungan yang positif yang cukup kuat antara variabel 
Kualitas Produk (X1) dengan Keputusan Pembelian (Y). Berdasarkan hasil perhitungan koefisien determinasi kualitas produk (X1) terhadap Keputusan Pembelian (Y) pada samartphone made in China sebesar 28,40\% dengan nilai signifikansi t sebesar $0,000<0,05$ yang berarti Ho ditolak dan Ha diterima. Berdasarkan analisa diatas dapat diambil kesimpulan terdapat pengaruh kualitas produk terhadap keputusan pembelian pada smartphone made in China di Kecamatan Cikupa Kabupaten Tangerang (secara parsial).

2. Dari hasil analisis data penelitian, didapat nilai hubungan (koefisien korelasi) antara variabel promosi (X2) dengan keputusan pembelian (Y) pada smartphone China di Kecamatan Cikupa Kabupaten Tangerang sebesar 0,648 yang berarti terdapat hubungan yang positif yang kuat antara variabel promosi (X2) dengan keputusan pembelian (Y). Berdasarkan hasil perhitungan korelasi Promosi (X2) terhadap keputusan pembelian (Y) pada samartphone made in china sebesar 41,99\% dengan nilai signifikansi t sebesar $0,000<0,05$ yang berarti Ho ditolak dan Ha diterima. Berdasarkan analisa diatas dapat diambil kesimpulan terdapat pengaruh promosi terhadap keputusan pembelian pada smartphone made in China di Kecamatan Cikupa Kabupaten Tangerang (secara parsial).

3. Berdasarkan hasil uji ANOVA atau uji $\mathrm{F}$ sebesar 50.068 dengan tingkat signifikansi $0.000<0.05$. Maka dapat disimpulkan bahwa variabel kualitas produk (X1) dan promosi (X2) secara simultan berpengaruh terhadap variabel keputusan pembelian (Y) pada smartphone made in China di Kecamatan Cikupa Kabupaten Tangerang. Sebagaimana terdapat pada model summary dengan nilai Adjusted $R$ Square $=0,498$ atau 49,8\%. 


\section{DAFTAR PUSTAKA}

Arikunto, Suharsimi. (2013). Prosedur Penelitian: Suatu Pendekatan Praktik. Jakarta: Rineka Cipta.

Kotler, dan Keller. 2012. Manajemen Pemasaran. Edisi 12. Jakarta: Erlangga.

Kotler, Philip. 2012. Prinsip-Prinsip Pemasaran. Alih Bahasa: A.B. Susanto. Jilid Idan 2. Penerbit Erlangga. Jakarta.

Kotler, Philip dan Amstrong, Gary, 2014, Principles of Marketin, 12th Edition, Jilid 1 Terjemahan Bob Sabran Jakarta : Erlangga.

Kotler, Philip \& Keller, Kevin Lane 2016. Marketing Management 15th Edition. New Jersey : Prentice Hall.

Lupiyoadi, Rambat. 2013. Manajemen Pemasaran Jasa Berbasis Kompetensi (Edisi 3). Jakarta: Salemba Empat.

Mursid, M. 2017. Manajemen Pemasaran. Jakarta : Bumi Aksara.

Mowen, John C dan Minor, Micheal. 2012. Perilaku Konsumen dialih bahasakan oleh Dwi Kartika Yahya. Jakarta : Erlangga.

Tjiptono, Fandy. 2014, Pemasaran Jasa (Prinsip, Penerapan, Penelitian). Yogyakarta. Andi.

2015. Strategi Pemasaran. Edisi 4. Yogyakarta: Andi.

2016. Service, Quality \& Satisfaction. Yogyakarta. Andi. 